\title{
INFLUENCE OF TRANSFORMATIONAL LEADERSHIP, TRUST AND EMPLOYEE EMPOWERMENT ON CORPORATE PERFORMANCE THROUGH INNOVATION AND REPUTATION IN MEDIUM AND LARGE ENTERPRISES
}

\author{
Fathurrahim ${ }^{*}$, Nimran Umar, Arifin Zainul, Musadieq M. Al \\ Faculty of Administrative Science, University of Brawijaya, Indonesia \\ ${ }^{*}$ E-mail: fathurrahim1102@gmail.com
}

\begin{abstract}
This study aims to develop an understanding of the influence of transformational leadership, trust and empowerment of employees on corporate performance through innovation and reputation in medium and large companies of West Lombok Regency, Indonesia. The sample used in this study is 153 company managers in West Lombok Regency analyzed using GSCA (Generalized Structured Component Analysis). The findings of this study contribute to the development of human resource management. Moreover, the practical contribution for the middle and big enterprise managers in West Lombok district is to improve corporate performance through transformational leadership style by taking into account the trust of employees and continuous employee's empowerment. Further research may include organizational and reward culture variables to expand and clarify this study.
\end{abstract}

\section{KEY WORDS}

Transformational leadership, trust, employee empowerment, innovation, reputation, corporate performance.

Corporate performance is the determination of certain measurement that can measure the success of a company in generating profits (Sucipto, 2003). The performance of the company in West Lombok Regency is considered inadequate in term of the low level of Human Resource education for the company, the inadequate use and mastery of technology, as well as the minimum guidance for the company from the government. Therefore, during this time the role of a leader in the company becomes very important.

Among the commonly used leadership styles is transformational leadership. The term transformational leadership was introduced by Bass (1985). Leaders are demanded to be competent in providing intellectual stimulation, in the form of giving stimulation and increasing creativity of their followers by developing the followers' mental state and innovative thinking (Bass and Avolio, 1994).

There has been considerable number of research that shows a positive relationship between transformational leadership and performance (Bass \& Riggio, 2006; Judge and Piccolo, 2004; Jung and Avolio, 2000). However, there are limited number of researches that discusses the effect of transformational leadership in an organization as a whole. Previous researches were focused more on a team or individual as is part of the organization.

The two critical elements in applying transformational leadership are employee empowerment and employee confidence in their leaders. According to Sigler (2000), employee empowerment helps employees feel that that they give meaningful contribution, that they are competent, and that they have choices in what they do. Meanwhile, employees' trust in their leaders also greatly influences their attitude in their daily work. Employees will be more courageous in taking risks in their work if they have strong confidence in their leaders (Kort \& Lewicka, 2012).

Another phenomenon that reveals the indirect influence of transformational leadership on performance is in mediation variables, including innovation and corporate reputation. According to Fontana (2011), innovation as a part of is possible because of the introduction of new ways or new combinations of old ways of transforming inputs into outputs (technologies) that results in large or drastic changes in the comparison of the perceived value from the customer of the benefit of a product (goods and / or services) and the prices 
set by the manufacturer. Reputation has become an important factor that can distinguish the company. It is also difficult to imitate may become the source of the company's financial performance (Hall, 1993; Robert and Dowling, 2002).

This research will be conducted in companies in West Lombok Regency. Companies in West Lombok Regency are dominated by tourism companies; some companies provide supports for tourism, such as craft and culinary business. The population of this study is medium and large companies.

\section{LITERATURE REVIEW}

Transformational Leadership. In describing transformational leadership style, Bass and Avolio (2003) states that true transformational leaders are: 1) leaders who are aware of what is right, good, and pleasing, 2) leaders who always help to raise the needs of their followers in achieving what is desired and in achieving actualization, 3) leaders who always help in achieving higher levels of moral maturity, and 4) leaders who can motivate their followers to let go of their individual interests for the good of the group, organization, and society.

Sarros and Butchatsky (1996) argue that transformational leadership is a breakthrough leadership. It is called so because leaders with this character have the ability to bring enormous changes to individuals and organizations by: reinventing individual character in organization or the organization itself, initiating innovation creation process, and reviewing structure, process and values of the organization to be better and more relevant in an interesting and challenging way for all parties involved and try to realize the organizational goals that had previously been considered impossible to be implemented (Daryanto and Daryanto, 1999: 12-13).

Transformational leadership increases the awareness of its followers by attracting ideals and values such as justice, peace and equality (Sarros and Santora, 2001: 385). Meanwhile, Humphreys (2005: 1413) states that leaders who have the transformational leadership style with the characteristics expressed by Bass (1985) will lead to a constant change to improve the organization. With these positive changes, the employees are ready to accept the task given by the leader without the burden, happy and satisfied in doing their job, and improve the productivity and performance of the employees concerned.

Trust. According to Rousseau, et al. (1998), trust is a psychological area that concerns accepting what is based on expectations of good behavior from others. Ba and Pavlou (2002) define trust as an assessment of one's relationship with others who will perform certain transactions according to expectations in an environment full of uncertainty. Trust occurs when one is convinced of the reliability and integrity of a trusted person (Morgan \& Hunt, 1994).

Moorman, et al. (1999) in Rusdin (2007) put forward the definition of trust as a statement between the two parties involved in a relationship. One party is considered to be acting as a controlling asset (having resources, knowledge) while the other parties sharing the resources in a bond will benefit them. One party's belief in the other will create an interactive behavior that will strengthen and help maintain that relationship. Such behavior will increase the length of the relationship by strengthening commitment. Ultimately, trust will is a valuable component to create a successful relationship. Such trust also reduces the risk of partnering and building long-term relationships and increase commitment in relationships.

Employee Empowerment. Based on research conducted by Cacciope (1998) at Burswood Resort Hotel Australia, empowered employees can solve organizational and customer problems quickly, instantly and professionally. Furthermore, empowerment is a good program because it causes changes in the organization, employee participation, and customer satisfaction. Nevertheless, management must also understand that achieving a certain level of empowerment is a long-term initiative and requires ongoing management commitment.

Employee empowerment gives employees more opportunities to develop creativity, flexibility and autonomy regarding their own work. This is believed to bring a beneficial effect in employee recognition (self-esteem). Employees will feel better and will think positively 
about themselves, therefore better equipped to serve the guests (Cacioppe, 1998). One way to encourage empowerment in the workplace is to identify and eliminate factors that can lead to feelings of powerlessness and replace them with factors that promote leadership, selfefficacy and internal motivation (Conger \& Kanungo, 1988).

Innovation. Freeman (2004) considers innovation as an enterprise effort through the use of technology and information to develop, manufacture, and market new products for the industry. In other words, innovation is a modification or discovery of ideas for continuous improvement as well as development to meet customer needs. Pervaiz K. Ahmed and Charles D (2010) argue that innovation can produce R \& D (Research and Development), production, and with marketing approaches, which ultimately lead to the commercialization of these innovations. In other words, innovation is the process of realizing new ideas, different from the old ones, by means of production or by making them real. Innovation includes generation of evaluation, new concepts and implementation.

Amabile et al. (1996) defines innovations as related to creativity: Innovation comes from the word to innovate which means making changes or introducing something new. Innovation is sometimes interpreted as a discovery, but it has different meaning. Discovery means finding something that has existed before, but is not yet known. While invention is a completely new finding of something that never exists before. According to Regis Cabral $(1998,2003)$, innovation is a new element that is introduced in a network that can change, although only for a moment, its price, its doer, its elements and nodes in the network.

Reputation. Jatmiko (2011) mentioned several aspects in establishing the company's reputation, including financial ability, product and service quality, customer focus, human resources excellence and sensitivity, reliability, innovation, environmental responsibility, social responsibility, and enforcement of good corporate governance (GCG). Aside from Jatmiko (2011), Spector (in Rosidah, 2011) also explains six factors in measuring a company's reputation: dynamic, cooperative, wiseness, good character, success, and restrain. A company is said to be dynamic when it as the following characteristics: pioneer, attractive, active and goal-oriented, is said to be when it is: friendly, likable, make people happy, and has good relations with others, considered wise when it is: wise, intelligent, persuasive, and well-organized, considered to have good character when it has: good ethics, good reputation. and honor, said to be success when it features a good and confident financial performance, and finally categorized having restrain when it is strict, confidential and cautious.

A company's reputation represents a network of affective or emotional reactions from consumers, investors, employees, and the public, whether it is good, bad, strong or weak, to the company's name (Frombun, 1996; 37). Corporate identity is a reflection or an understanding of how the employees work, how the product is made, how the stakeholders are served, and so on.

Corporate Performance. Hurduzeu (2015) states that the overall performance of the company can be defined as a change or transformation of inputs into outputs to achieve certain goals. Depending on the context, performance can show the relationship between minimal and effective cost, between effective cost and and output (efficiency), and between the output and the objectives achieved (effectiveness). Prawirosentono (2008) offers factors that affect the performance of the organization, namely:

1. Effectiveness and Efficiency. An organization or group is said to be effective when group goals can be achieved according to its plans. While efficiency is related to the amount of sacrifices incurred in certain achievements.

2. Responsible. Responsibility is an integral part or partial effect of the ownership of such authority.

3. Discipline. Discipline is obedience to laws and regulations. Employee discipline is the employee's obedience in respecting the employment agreement with his company.

4. Initiative. One's initiative is related to thinking power, creativity in the form of ideas for something related to organizational goals. A good boss should give attention or positive response for every initiative. 
The research follows up on the first assumption that transformational leadership, trust, employee empowerment, innovation and reputation can be implemented well and can not be separated. The study was based on other researches such as Alsalamy, Beheri and Abdullah (2014), Husain, Talib and Shah (2014), Yusoff, et al., (2015), Krot and Lewicka (2012), Roberts and Dowling (2002), Mano, Thoyib, Maskie and Djumahir (2014) and Men and Stacks (2012).

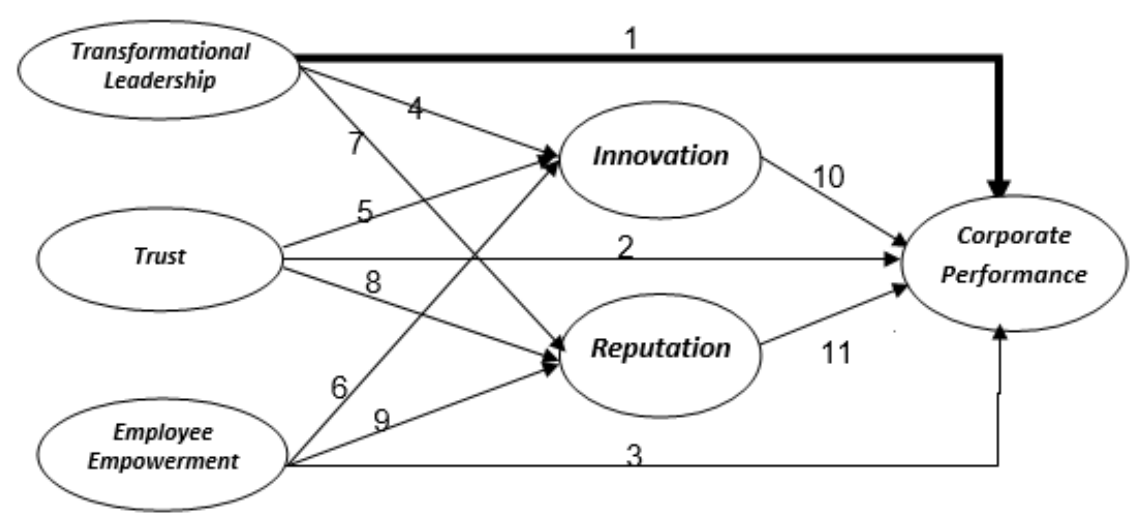

Figure 1 - Model Hypothesis

Hypotheses:

Relationship between Transformational Leadership and Corporate Performance

There are three reasons which stated that "transformational leadership activities that have an effect on corporate performance improvement, first, leaders care not only in organizational performance but also all things including company resources. Second, a strong recording of transformational leadership can create the desired image that encourages trust and empowerment of employees through innovation and reputation to positively evaluate company behavior. Third, transformational leadership initiatives become a key element of corporate identity. Thus, the hypothesis formulation is:

$\mathrm{H} 1$ = transformational leadership has a positive effect on corporate performance.

Relationship between the Trust and Corporate Performance

Trust in a company is defined as a belief that the provider of a product or service can act variously to meet the long-term needs of the service. That "to achieve improvements the company's performance should earn trust. Furthermore, trust is considered the key to building relationships within the company. Trust has two components: (1) performance or credibility of trust; and (2) good / sincere belief. From this context the hypotheses that can be formulated are:

$\mathrm{H} 2$ = trusts positive effect on corporate performance.

Relationship between Employee Empowerment and Corporate Performance

Batten (1995) adds that the empowerment of employees can help both public and private companies in achieving increased performance, because when employees feel empowered, then it can have an impact on the performance of employees so as to make the customer be more satisfied and loyal. The hypothesis formulated is:

$\mathrm{H} 3$ = Employee empowerment positive effect on corporate performance.

Relationship between Transformational Leadership and Innovation

One manifestation of the commitment of transformational leaders is to open the widest space to employees to innovate. One form of innovation, for example, is the use of information technology (information technology) in all activities within the company. Leaders believe that by utilizing information technology, the company's performance will increase. Thus, the hypothesis of this study is:

$\mathrm{H} 4=$ transformational leadership positive effect on innovation.

Relationship between the Trust and Innovation 
To maintain internal trust, the company is willing to pay a large amount of money. Trust companies will result in many benefits, both financial and non-financial. One of the hard efforts it is competing to innovate, for example, by utilizing information technology. For example, e-commerce, e-banking, and others. Thus, the hypothesis of this study is:

$\mathrm{H} 5=$ trusts positive effect on the use of innovation.

Relationship between Employee Empowerment and Innovation

Empowered employees have better knowledge, attitudes, and behaviors for tasks within the organization than unemployed employees. Increased knowledge, attitudes, and behaviors are reflected in new techniques chosen in the performance of tasks to achieve efficiency and effectiveness. New techniques referred to, for example by choosing to use information technology to support the achievement of its best performance. Thus, the research hypothesis can be formulated:

H6 = Employee empowerment positive effect on innovation.

Relationship between Transformational Leadership and Reputation

Reputation is seen as extrinsic motivation for companies to carry out the activities of leadership transformational the. Thus, a reputation earned should be seen as the relevant outcomes of leadership transformational (Garberg and Fombrun, 2006) in Maden, et al., (2012). Studies on the relationship between leadership transformational the reputation of a company perspective that firms perceive leadership policy transformational can also be found in companies that perceive the reputation, then the hypothesis is:

$\mathrm{H} 7$ = Transformational leadership positive effect on the reputa tion.

Relationship between Trust and Reputation

Park, et al, (2014) describes trust as an intermediary variable that order in the practice of leadership transformational can positively impact on reputation. That to create a reputation requires a strong integrity of trust both from the aspect of legal and ethical responsibility. In addition, the reputation is determined by the Trust-rooted social good and responsibility towards helping behavior (philanthropic). From this perspective, the hypothesis formulation is:

$\mathrm{H} 8=$ Trusts positive effect on reputation .

Relationship between Employee Empowerment and Reputation

Empowered employees have better knowledge, attitudes, and behaviors for tasks within the organization than unemployed employees. Increased knowledge, attitudes, and behaviors are reflected in new techniques chosen in the performance of tasks to achieve efficiency and effectiveness. Companies with the best performance will get a good reputation as well. Thus, the hypothesis of this study is:

$\mathrm{H} 9=$ Employee empowerment take effect positive to reputation.

Relationship between Innovation and Corporate Performance

Innovation can be done with various things. Starting from creating new goods or services, the process of manufacturing and delivery of goods more efficiently, and others. The innovation process will run more smoothly if it is followed by the use of information technology. In addition to operational efficiency, the company also makes use of information technology for suppliers, sales channels and customer collaboration in order to meet customer needs most effectively (Gunasekaran \& McGaughey, 2002). Thus, the research hypothesis can be formulated as follows.

$\mathrm{H} 10=$ Innovation positive effect on corporate performance.

Relationship between Reputation and Corporate Performance

Reputation will provide logical consequences for the company's long-term financial performance, customer loyalty, customer trust, and commitment. The more obvious as shown by Doorley and Garcia (2007) that the reputation of a number of images, together with the performance and behavior and communication. Of the elements that make it up, consisting of organizational ethics reputation, financial performance, the value of stock ownership, activity, corporate branding, marketing mix activities, public relations, and relations with stakeholders (Le Roux, 2003). Thus, the hypothesis can be formulated:

$\mathrm{H} 11=$ Reputation positive effect on corporate performance. 


\section{METHODS OF RESEARCH}

Six variables were observed in this research: transformational leadership, trust, employee empowerment, innovation, reputation and corporate performance. A total of 21 items were observed an independent measurement of exogenous variables that transformational leadership consists of four items, the trust consists of four items, employee empowerment consists of six items, innovation consists of three items and reputation consists of four items. The endogenous variable corporate performance consists of 4 items. The measurement scale of the questionnaire is 5 points Likert Scale namely 1-strongly disagree, 2-disagree, 3-waver, 4 - agree, 5-strongly agree. Identification of variables by sex, marital status, age, last education and duration of work.

The target population in this study was the manager in medium and large corporation in the West Lombok Regency, a total of 248 companies. Samples were taken with a Slovin formula. The number of samples used were 153 managers of the company. The sampling technique used was proportional random sampling area with distribution area in 10 (ten) districts in West Lombok regency.

In this research, inferential statistics will be used to test the effect of transformational leadership sample data, trust, employee empowerment, innovation and reputation to corporate performance. Inferential statistics used are GSCA (Generalized Structured Component Analysis). GSCA by Ghozali (2008) is part of Component Based SEM and offers global least square optimization criteria, which consistently minimize to get model parameter estimates. GSCA is also equipped with the overall fit model size. GSCA can be used to confirm the theory, but it can also be used to explain whether or not the relationship exists between latent variables.

\section{RESULTS OF STUDY}

Profiles of respondents. Based on 147 questionnaires returned from the 153 questionnaires distributed, the individual profiles involved in the study showed the majority of male respondents (59.9\%) and the rest are women $(40.1 \%)$. Individual profiles based on marital status indicate that most of the respondents are married $(78.9 \%)$ and unmarried $(21.1 \%)$. Most individuals were aged $31-40$ years $(34.7 \%), 41-50$ years $(32.7 \%), 20-30$ years $(27.2 \%)$ and above 50 years $(5.4 \%)$.

Individual profiles based on the last level of education, most of them are bachelor $(51.0 \%)$, diploma $(23.8 \%)$, higschool $(23 \%)$ and graduate $(9.5 \%)$. While based on the duration of working in the company, most have worked more than 5 years (46.9\%), 3-5 years $(35.4 \%)$ and 2 years $(17.7 \%)$.

Construct validity, dimensionality and reliability. Based on the results of the model analysis it can be seen that all indicators that measure transformational leadership variables, trust, employee empowerment, innovation, reputation and company performance resulted in loading factor greater than 0.6. Thus, indicators that measure transformational leadership variables, trust, empowerment of employees, innovation, reputation and performance of the company can be declared valid or able to measure these variables.

Discriminant reliability results show that the value of Cronbach's alpha is greater than 0.6 and the discriminant reliability value is greater than or equal to 0.5 Therefore, based on the AVE value, all indicators that measure the variable are declared reliable. Furthermore, the value of Cronbach's alpha transformational leadership variables, trust, employee empowerment, innovation, reputation and company performance is greater than the value of cut off value of 0.60 . It means that based on Cronbach's alpha, all indicators that measure these variables are declared reliable.

Model Analysis. The first stage of testing uses GCSA, or the Goodness of Fit Model. Goodness of fit model is intended to determine whether the constructed forms are suitable or not. There is several goodness of fit index in GSCA analysis that is Fit, AFit, GFI, and SRMR. The GFI criteria stated that if the value of GFI $\geq$ the cut off value (equal to 0.90 ) then the model stated as good fit, while if the GFI value is within the range 0.8 to 0.9 then the model is 
stated as marginal fit. While the FIT value shows how much exogene variable is able to explain its endogen variables.

From the result of goodness of fit mode, it is known that the index of global optimization or GFI is 0.968 . This shows GFI> 0.9. Thus, the GSCA model as a whole against the intention of behaving concluded as good fit. Based on the goodness of fit structural model obtained Fit is 0.620 . This means the contribution of transformational leadership variables, trust, employee empowerment, innovation, and overall reputation to the company's performance of $62.0 \%$. Meanwhile the contribution of other variables that are not discussed in this study is $38.0 \%$. Other things that may affect the company's performance include organizational culture and reward or punishment within the company.

Next is the testing of hypothesis by using the criteria of testing which stated that if the critical ratio $(C R) \geq t$-table $(t=2.00$, alpha $=5 \%$ ) then exogene variables influence to endogene variables. The test results of direct link are shown in Table 1 below:

Table 1 - Direct Effect Test Result

\begin{tabular}{|c|c|c|c|c|c|}
\hline Exogene & Endogen & Path Coefficient & SE & CR & Conclusion \\
\hline KT & $\mathrm{I}$ & 0.123 & 0.081 & 1.52 & Rejected \\
\hline KT & $\mathrm{R}$ & 0.488 & 0.12 & 4.07 & Accepted \\
\hline KT & $\mathrm{KP}$ & 0.427 & 0.154 & 2.78 & Accepted \\
\hline K & $\mathrm{I}$ & 0.257 & 0.075 & 3.41 & Accepted \\
\hline K & $\mathrm{R}$ & 0.338 & 0.089 & 3.81 & Accepted \\
\hline K & $\mathrm{KP}$ & -0.248 & 0.122 & 2.03 & Accepted \\
\hline PK & $\mathrm{I}$ & 0.572 & 0.076 & 7.48 & Accepted \\
\hline PK & $\mathrm{R}$ & 0.017 & 0.125 & 0.14 & Rejected \\
\hline PK & $\mathrm{KP}$ & -0.021 & 0.176 & 0.12 & Rejected \\
\hline I & $\mathrm{KP}$ & 0.247 & 0.192 & 1.29 & Rejected \\
\hline R & $\mathrm{KP}$ & 0.19 & 0.149 & 1.28 & Rejected \\
\hline
\end{tabular}

Source: processed primary data (2017).

The influence of transformational leadership on innovation produces a critical ratio (CR) value of 1.52. This shows that the critical ratio value $(C R)$ is unmarked or $(C R<$-table $=$ 2.00, $($ alpha $=5 \%)$ ). Therefore, it can be interpreted that there is no significant effect of transformational leadership on innovation.

The influence of transformational leadership on reputation generates a critical ratio $(C R)$ value of $4.07^{*}$. This indicates that the critical ratio value $(C R)$ is marked or (CR>t-table $=2.00$, $($ alpha $=5 \%)$ ). Therefore, it can be interpreted that there is a significant effect of transformational leadership on reputation.

The influence of transformational leadership on corporate Performance resulted in a critical ratio (CR) of $2.78^{*}$. This indicates that the critical ratio value $(C R)$ is marked or $(C R>t-$ table $=2.00$, $($ alpha $=5 \%))$. Therefore, it can be interpreted that there is a significant influence of transformational leadership on corporate performance.

The effect of trust on innovation produces a critical ratio (CR) of $3.41^{*}$. This indicates that the critical ratio value $(C R)$ is marked or $(C R>t$-table $=2.00$, (alpha $=5 \%)$ ). Therefore, it can be interpreted that there is a significant influence of trust on innovation.

The influence of trust on reputation generates a critical ratio (CR) of $3.8^{*}$. This indicates that the critical ratio value $(C R)$ is maked or $(C R>t$-table $=2.00$, $($ alpha $=5 \%))$. Therefore, it can be interpreted that there is a significant influence of reputation on trust.

The influence of confidence on corporate Performance resulted in a critical ratio (CR) of $2.03^{*}$. This indicates that the critical ratio value $(C R)$ is marked or $(C R>t$-table $=2.00$, $($ alpha $=5 \%))$. Therefore, it can be interpreted that there is a significant influence of trust on the performance of the company.

The influence of employee empowerment on innovation resulted in a critical ratio (CR) of $7.48^{*}$. This indicates that the critical ratio value $(C R)$ is marked or $(C R>t$-table $=2.00$, $($ alpha $=5 \%))$. Therefore, it can be interpreted that there is a significant effect of employee empowerment to innovation. 
The influence of employee empowerment on reputation produces a critical ratio (CR) value of 0.14 . This shows that the critical ratio value $(C R)$ is unmarked or $(C R<$-table $=$ 2.00, (alpha $=5 \%)$ ). Therefore, it can be interpreted that there is no significant effect of employee empowerment to reputation.

The effect of employee empowerment on corporate Performance resulted in a critical ratio $(C R)$ of 0.12 . This shows that the critical ratio value $(C R)$ is unmarked or $(C R<t-t a b l e=$ 2.00, $($ alpha $=5 \%))$. Therefore, it can be interpreted that there is no significant effect on employee empowerment of corporate Performance.

The effect of innovation on corporate performance resulted in a critical ratio (CR) of 1.29. This shows that the critical ratio value $(C R)$ is unmarked or $(C R<t$-table $=2.00$, (alpha $=5 \%)$ ). Therefore, it can be interpreted that there is no significant effect of innovation on corporate performance.

The influence of reputation on corporate Performance resulted in a critical ratio (CR) of 1.28. This shows that the critical ratio value $(C R)$ is unmarked or $(C R<t$-table $=2.00$, (alpha $=5 \%)$ ). Therefore, it can be interpreted that there is no significant influence of reputation on the performance of the company.

Based on the hypothesis test, the result of test relationships between variables of the research hypothesis after testing using the software GSCA is presented in Figure 2.

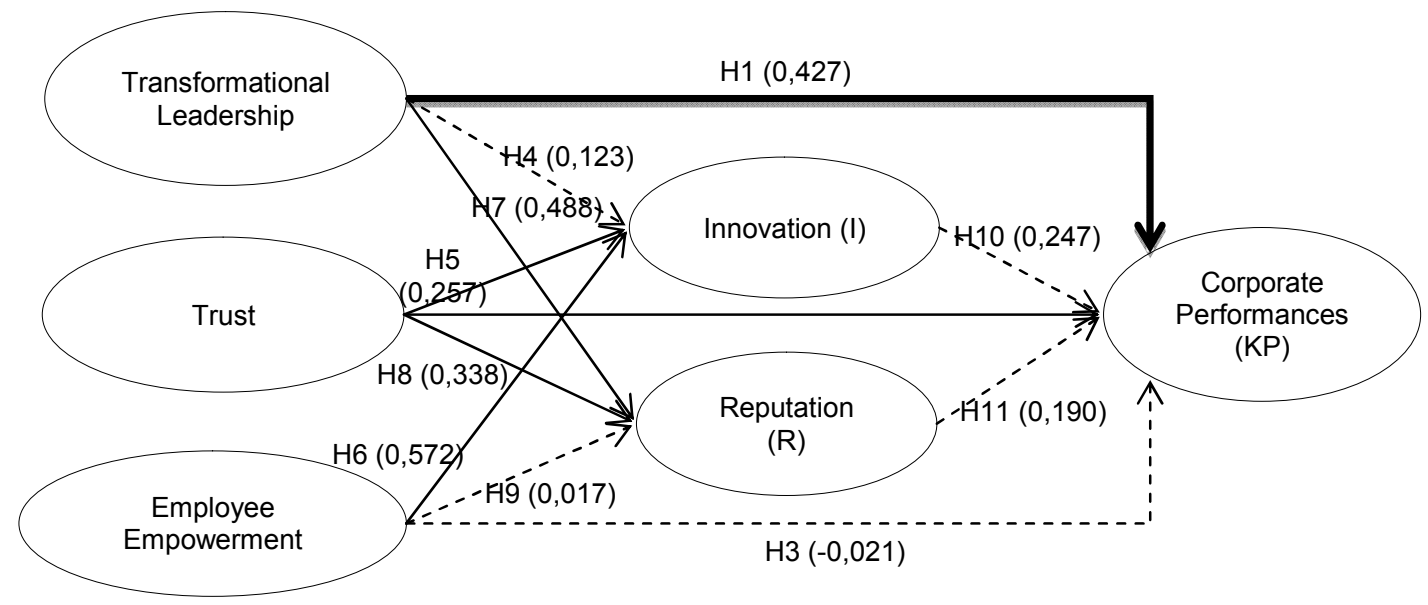

Figure 2 - Tested Hypothesis Model

Thin black line: Significant inter-variable relationship based on research contribution

Thick black line: New relationship between variables is significant

Dotted lines: The relationship between variables is not significant

Table 2 - Indirect Effect Hypothesis Test Results

\begin{tabular}{|l|l|l|l|l|l|}
\hline Exogene & Mediation & Endogen & Indirect Coefficient & SE & T Statistics \\
\hline KT & I & KP & 0.030 & 0.031 & 0.982 \\
\hline KT & R & KP & 0.093 & 0.076 & 1.217 \\
\hline K & KP & 0.063 & 0.053 & 1.204 \\
\hline K & R & KP & 0.064 & 0.053 & 1.209 \\
\hline PK & K & KP & 0.141 & 0.111 & 1.268 \\
\hline PK & R & KP & 0.003 & 0.024 & 0.135 \\
\hline
\end{tabular}

Source: processed primary data (2017).

Then, the results of the analysis of mediation variables show no relationship involving the mediation variables. Test results for indirect relationships between variables can be summarized in Table 2. It shows that transformational leadership, trust and employee empowerment do not have an indirect relationship to corporate Performance through innovation or reputation. 


\section{DISCUSSION OF RESULTS}

The results showed positive and significant relationship between transformational leadership on corporate performance. The findings of this study confirm and elaborate the opinion of Bass (1990), Robbins (1996), Hersey, et al. (1996), Barney (1991), Wang (2014). Also Wang's opinion, et al. (2011) and is an update of the previous studies because the current study percieve transformational leadership within an organization, not individually therefore it elaborates Wang's, et al. (2011).

The results showed that trust had a negative and significant effect on corporate Performance. The findings of this study confirm and elaborate the research of Brown, et al., (2011), Krot and Lewicka (2012), Tzafir (2009) that belief has a positive and significant impact on corporate Performance. Rao A.N (2015) also states that trust affects team performance.

The results of the study found that employee empowerment has a negative but not significant effect on the corporate Performance. The results of this study contradict with the research from Batten (1995) and Spritzer (2008) which states that when employees feel empowered in the workplace, it will produce positive things that lead to the improvement of performance, productivity and initiative.

Other researches results are transformational leadership has positive and insignificant effect on company innovation. The results of this study differ from Khan, et al. (2009) and Tipu, et al. (2012) research which states that many studies have examined the factors that can remind innovation within the organization, and they agree that leadership, especially the transformational leadership style, is one of the important factors.

Furthermore, the results of this study found that employee confidence has a significant effect on corporate innovation. The results of this study confirm and expand the opinion of Sankowska (2013), Krot and Lewicka (2012) stating that trust has been proven in improving the innovative nature of an organization. Feelings of confidence and trust in partners are increasing the intensity of relationships among colleagues, so it is easy to achieve the company innovation.

The results of this study revealed that employee empowerment has a positive and significant impact on company innovation. In addition, the result of this study supports and elaborates the opinions of Conger and Kanungo (1988) and Spreitzer (1995), and also supports the results of previous research from Alraja and Alomiam (2013), Noorshargh, et al., (2015), Husyein (2015).

Other research findings show that transformational leadership has positive and significant impact to the company's reputation. The results of this study confirm and elaborates the statement of Sarros and Butchatsky (1996), Robbins (1996), Garberg and Fombrun (2006) and Bitner and Zeithaml, et al. (2006).

Furthermore, this study revealed that employee confidence has a positive and significant impact on the company's reputation. The results of this study confirm and broaden the opinion of Morrow, et al. (2005), Usmara (2006), Park, et al. (2014) and Thorsten, Gwimmer, and Gremier (2002).

The results of the further research is that there is a positive influence between employee empowerment with reputation, but not significant. The results of this study differ from the studies conducted by Cacciope (1998) and Spreitzer (1995) but support research from Kele, et al. (2017) and Baird and Wang (2008).

The results of this study indicate that innovation has an effect but not significant to corporate Performance. This is supported by Cheng and Shiu (2014), Taylor (2003), D'Este, et al. (2012) and Blind, et al. (2016) research. The results of this study differ from Caglar's, et al. (2006) and Mclyor, et al. (2000) research.

Other results found that there was a non-significant influence between reputations on corporate Performance. The results of this study do not support previous research from Ali, et al. (2014), Doorley and Garcia (2007) and Stuebs and Sun (2010). 


\section{CONCLUSION}

The results of research indicate that there is direct influence between variables and the absence of indirect relationship. The results of his research are: first, transformational leadership has a positive and significant impact on corporate performance. Second, trust has a negative and significant effect on corporate performance. Third, employee empowerment has negative and insignificant effect to corporate performance. Fourth, transformational leadership on innovation is positive and insignificant on corporate performance. Fifth, employee trust has a positive and significant impact on company innovation. Sixth, employee empowerment has a positive and significant impact on company innovation. Seventh, transformational leadership has a positive and significant effect to the company reputation. Eighth, employee's trust has a positive and significant impact on the company reputation. Ninth, employee empowerment has a positive and insignificant effect on company reputation. Tenth, innovation has a positive and insignificant effect on corporate Performance. Eleventh, reputation has a positive and insignificant effect on corporate Performance.

This research also provides practical contribution that can be applied in the field of human resources and contributing to the development of science. The results of this study can provide a tangible contribution to corporate managers in the context of the impact of the typical implementation of transformational leadership, trust, and employee empowerment on corporate performance through innovation and corporate reputation. It can directly or indirectly improve corporate Performance. Because employees will participate determine the willingness to participate in carrying out the company activities, it is necessary to build trust between employees and always do the employee empowerment.

This research is cross-sectional so it cannot see the dynamics of what is studied over time especially related to transformational leadership, trust, employee empowerment, innovation, and reputation variables in companies in West Lombok District.

The research findings that the contribution of transformational leadership, trust, empowerment of employees, innovation, and reputation variables as a whole to the company's performance is $62,00 \%$, while the rest of $38,00 \%$ is the contribution of other variables that are not discussed in this research. Further research can add other variables such as organizational culture variables and rewards that can contribute to the performance of the company.

\section{REFERENCES}

1. Alraja \& Alomiam. (2013). The Effect Of Information Technology In Empowerment Public Sector Employees: A Field Study, Interdisciplinary Journal Of Contemporary Research In Business. Vol. 5, No. 1.

2. Amabile, T. M., Conti, R., Coon, H., Lazenby, J., \& Herron, M. (1996). Assessing the work environment for creativity. Academy of Management Journal. Vol. 39, 1154-1184.

3. Avolio, B.J., Bass, B.M., and Jung, D.I. (1999). Re-Examining The Components of Transformational and Transactional Leadership Using The Multifactor Leadership Questionnaire. Journal of Occupational and Organizational Psychology. Vol 2, No. 4, 441-426.

4. Bass, B.M., Avolio, B.J., Jung, D.I., Berson, Y. (2003). Predicting Unit Performance by Assesing Transformational and Transactional Leadership. Journal of Apllied Psychology, Vol. 88.

5. Bass, B.M. and Avolio, B.J. (1994). Improving Organizational Effectiveness Through Transformational Leadership, Sage: Thousand Oaks.

6. Batten, D.F. (1995). Network Cities : Creative Urban Agglomeration for the 21st Century, Urban Studies, vol. 32, no. 2, 313-327; 1995.

7. Bitner, M. J. dan Zeithaml, V. A. (2003). Service Marketing (3rd ed.), Tata McGraw Hill. New Delhi. 
8. Cabral, Regis. (2003). Development, Science and in Heilbron, J. (ed.), The Oxford Companion to The History of Modern Science. Oxford University Press. New York: 205207.

9. Cacioppe, R. Robbins, S., Millett, B., \& Waters-Marsh, T. (1998), Organizational Behaviour: Leading \& Managing in Australia and New Zealand, Prentice Hall, Sydney.

10. Conger, J. A., \& Kanungo, R. N. (1988). The empowerment process: integrating theory and practice. Academy of Management Review, 13, 471.482.

11. Daryanto, A. dan H.K.S. Daryanto. (1999). Model Kepemimpinan dan Profil Pemimpin Agribisnis di Masa Depan. AGRIMEDIA, Vol. 15, No. 2.

12. Doorley, John, dan Fred Garcia. (2007). Reputation Management: The Key to Successful Public Relation and Corporate Communication. London \& NewYork: Taylor \& Francis Group.

13. Fontana, Avanti dan Vincent Gasperz. (2011). Integrated Management Problem Solving. Vinchristo Publication. Bogor.

14. Freeman, R.E. (2004). A Stakeholder Theory of Modern Corporations. Ethical Theory and Business, 7th ed.

15. Fombrun, Charles. J. (1996). Reputation: Realizing Value from the Corporate Image. Harvard Business School Press. USA

16. Gunasekaran, A. and McGaughey, R. (2002). Information Technology/Information Systems in 21st Century Manufacturing. International Journal of Production Economics. Vol.75,1-6.

17. Hurduzeu, R. (2015). The impact of leadership on organizational performance. Practical Application of Science, Vol. 3, No. 7, 289-294.

18. Husyein. (2015). The impacts of employee empowerment on innovation: a survey on isparta and burdur organized industrial zones. The Journal of International Social Research, Vol. 8, No.37, April 2015.

19. Jatmiko, I. (2011). Kajian Citra Perusahaan Melalui Kegiatan Corporate Social Responsibility pada Bank "X" Bogor. Program Sarjana Alih Jenis Manajemen Departemen Manajemen Fakultas Ekonomi Dan Manajemen Institut Pertanian Bogor, Bogor.

20. Khan, R. Rehman, A.U. and Fatima, A. (2009). Transformational leadership and organizational innovation: Moderated by organizational size. African Journal of Business Management. Vol. 3, No. 11, 678-684.

21. Krot, K. and Lewicka, D. (2012). The importance of trust in manager-employee relationships. International Journal of Electronic Business Management, vol. 10, no. 3, 224-233.

22. Le Roux, Johanna Regine Josèphe. (2003). Corporate Reputation in the Information Technology Industry: a South African Case Study. University of Pretoria. Pretoria.

23. Mclyor, R., Humpheys, P and Huang, G. (2000). Electronic Commerce: Reengineering the Buyer-Supplier Interface. Business Process Management Journal, Vol. 6, No.2.

24. Moorman. C, Deshpande. R dan Zaltman. G. (1993). Actors Affecting Trust in Market Relationship. Journal of Marketing, Vol. 58.

25. Morgan, R dan Hunt, S. (1994). The commitment- trust theory of the relationship marketing. Journal of Marketing Reserch Vol.58, 20-38.

26. Morrow, Paula. C, Yoshinori Suzuki, Michael R. Crum. Robert Ruben dan Gregory Pautsch. (2005). The role of leader-member exchange in high turnover work environments. Journal of Managerial Psychology Vol. 20, No. 8, 681-694.

27. Noorshargh. (2015). Investigating the Impact of Information Technology on empowering employees (Case Study: South Pars Oil Company), Visi Jurnal Akademik No. 2,1-10; 2015

28. Park, Jongchul, Hanjoon Lee dan Chankon Kim. (2014). Corporate Social Responsibilities, Consumer Trust And Corporate Reputation: South Korean Consumers' Perspectives. Journal of Business Research, Vol. 67, pp 295-302. 
29. Pillai, R. Schriesheim, C.A William, (1999). Fairness perceptions and trust as mediators for transformational and transactional leadership: a two sample study, Journal of Management, Vol. 25, No.6, 897-933.

30. Robbins, Stephen P. (1996). Perilaku Organisasi, Konsep, Kontroversi dan Aplikasi. Alih Bahasa : Hadyana Pujaatmaka. Edisi Keenam. PT.Bhuana Ilmu Populer. Jakarta.

31. Rousseau, D.M., S.B. Sitkin, R.S. Burt, and C. Camerer. (1998). Not So Different After All: A Cross-Discipline View of Trust. Academy of Management Review, Vol.23, 393-404.

32. Rusdin. (2007). Teori, Masalah dan Kebijakan dalam Praktik. Alfabeta. Bandung.

33. Rosidah, C. (2011). The Influence of Corporate Reputation and Trust To Consumer Loyalty of ATM Users After Cyber crime Isues (Study at BCA Consumers in Surabaya). Jurnal Business and Economics.

34. Sankowska, Anna. (2013). "Relationships between organizational trust, knowledge transfer, knowledge creation, and firm's innovativeness". The Learning Organization, Vol. 20 No. $1,85-100$

35. Sarros, J.C. dan J.C. Santora. (2001). The transformational-transactional leadership model in practice. Leadership \& Organization Development Journal. Vol. 22, No. 8, 383393.

36. Sarros, J.C dan Butchatsky, O. (1996). Leadership. Harper-Collins. Sydney.

37. Spreitzer, G.M. (2008). "Taking stock: a review of more than twenty years of research on empowerment at work" in Barling, J. and Cooper, C.L. (Eds). The Sage Handbook of Organizational Behavior, Sage, Thousands Oaks. CA.

38. Tipu, S.A.A., Ryan, J.C. and Fantazy, K.A. (2012). Transformational leadership in Pakistan: An examination of the relationship of transformational leadership to organizational culture and innovation propensity. Journal of Management \& Organisation, Vol. 18, No. 4, 461-480.

39. Wang. H. 2014. How Relational Capital Mediates The Effect Of Corporate Reputation On Competitive Advantage: Evidence From Taiwan High-Tech Industry. Technological Forecasting \& Social Change. Vol. 82, 167-176. 